\title{
As boas novas da "velha" Medicina Legal
}

\author{
Talita Zerbini
}

\begin{abstract}
A Medicina Legal, em seu conceito clássico, é a "aplicação dos conhecimentos médicos e biológicos na elaboração e execução das leis que deles carecem" (Flamínio Fávero, 1991). Em outras palavras, a especialidade surgiu como uma ponte entre a Medicina e o Direito, sendo responsável por transformar o "mediquês" para uma linguagem inteligível para o meio jurídico e por traduzir o "juridiquês" para os médicos.
\end{abstract}

Quando tinha 12 anos, minha irmã mais velha cursava Direito na USP e estudava em casa durante a noite. Como éramos muito ligadas, por vezes eu ficava ao seu lado enquanto ela estudava. Em um desses dias, ela estava com um livro de Medicina Legal aberto na mesa e, como sempre, comecei a ler junto. Após alguns minutos, já estava puxando o livro para mim e pensando: "é isso que quero fazer da vida".

Durante a graduação pensei em fazer Cirurgia de Cabeça e Pescoço, tendo inclusive feito muitos estágios na área. Porém, no final da faculdade passei a ter muitas dúvidas a respeito da minha escolha, pois não tinha certeza se realmente tinha vocação para isso. Na metade do sexto ano, então, a solução dos meus problemas apareceu: a Residência em Medicina Legal. No início, enfrentei muito preconceito pela falta de conhecimento da maioria a respeito da área, pois a todo momento me falavam que eu estava desperdiçando seis anos de faculdade para ir "mexer com morto" no IML e que eu estava optando por deixar de ser médica. Apesar da opinião da maioria, inclusive dos meus colegas de turma, fui em frente e entrei na
Residência logo após o término da graduação. Posso dizer agora que foi a melhor escolha que fiz.

A Residência em Medicina Legal é muito mais ampla do que o Instituto Médico Legal (IML), que realiza as perícias criminais. Durante os três anos de Residência, aprendemos que o especialista em Medicina Legal é o médico que pode realizar todos os tipos de perícias médicas: previdenciárias, cíveis, trabalhistas, securitárias, criminais, auditorias, entre outras. O único problema ao virar "ex-residente" era mostrar para todos, a realidade: comecei a fazer "propaganda" da nossa especialidade, mostrando para os juízes de todas as áreas o que realmente era capaz de fazer, sempre amparada pelo Supervisor da Residência Médica, Professor Daniel Romero Muñoz. Aos poucos, as pessoas ligadas ao Direito começaram a entender que os formados nessa Residência não eram exclusivamente potenciais médicos legistas concursados do IML, mas que estávamos aptos a fazer qualquer tipo de perícia médica. Assim, comecei a trabalhar nas mais diversas áreas periciais, e atualmente chego ao ponto de recusar trabalhos pelo grande volume de perícias que tem aparecido. Realmente as pessoas estavam certas em um ponto: faço necropsias sim (e é com grande satisfação profissional que as faço), mas não exclusivamente isso.

Passados cinco anos da graduação, o retorno financeiro tem sido muito bom, mas o que considero mais importante é a satisfação em ter escolhido essa especialidade, que me faz muito feliz e realizada profissionalmente. 